\title{
PROFESIONALISME GURU MATA PELAJARAN PENDIDIKAN AGAMA ISLAM DAN BUDI PEKERTI SD 200205 \\ PADANGSIDIMPUAN
}

Oleh:

\author{
Maulana Arafat ${ }^{1}$
}

\begin{abstract}
Abstarct
Teacher professionalism in not as slogan anymore, but it has become a job or activity that must be done. This research aims to describe students respond, stakeholders and headmaster of elementary school 200205 in Padangsidimpuan city toward teacher professionalism of Islamic education and character lesson. This is field research in qualitative descriptive where in this research, the researcher looks for and uses descriptive data such as words or utterance, opinions from research subject either orally or in writing. Data collections are conducted with interview and documentation method. Analysis technique is begun of data reduction, data presentation and conclusion. Data analysis is conducted while data is collected and after all data are collected or after the research is done. The result ofresearch shows that the respond of student, stakeholder and headmaster elementary school 200205 Padangsidimpuan city is good in aspect of subject mastery, learning media use, and learning strategies application. However, preparation of learning device before beginning the study need to be improved such as making annual programs, semester programs, syllabus, lesson plans, and assessmentas that stiil out of expectatios. Therefore this research is done so that teacher in Islamic education and character lesson is able to be professional educator based on competence.
\end{abstract}

Keywords: Professionalism, Teacher, Islamic Education and Character Lesson in Elementary School 200205 Padangsidimpuan

\section{PENDAHULUAN}

Menurut UU No Tahun 2003, pendidikan adalah usaha sadar dan terencana untuk mewujudkan suasana belajar dan proses pembelajaran agar siswa secara aktif mengembangkan potensi dirinya untuk memiliki kekuatan spiritual keagamaan. Pengendalian diri, kepribadian, kecerdasan, akhlak mulia, serta keterampilan yang diperlukan dirinya, masyarakat, bangsa, dan negara ${ }^{2}$. Untuk itu agar terlaksananya pendidikan yang baik perlu seseorang yang mampu mendidik, mengajar, membimbing

\footnotetext{
${ }^{1}$ Penulis Adalah Dosen PGMI-FTIK IAIN Padangsidimpuan Gmail:

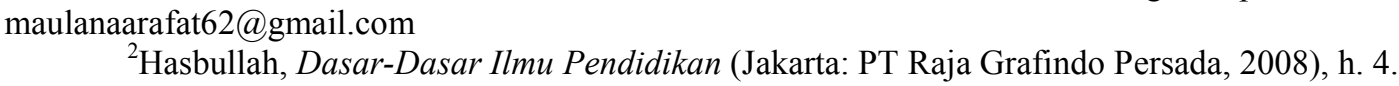


dan membentuk seseorang yang lainnya. Dengan kata lain bahwa, kehadiran seorang pendidik sangat dibutuhkan demi terselenggaranya tujuan pendidikan Nasional yang dimaksud. Untuk lebih jelasnya maka para pendidik tersebut sering atau biasa disebut dengan guru.

Kehadiran guru sebagai salah satu sumber belajar berkewajiban menyediakan lingkungan belajar yang kreatif dan kondusif. Menjadi guru kreatif, inovatif, dan menyenangkan dituntun untuk memiliki kemampuan memilih strategi pembelajaran yang sesuai dengan keadaan, sehingga minimbulkan pembelajaran yang bervariasi. Hal ini penting untuk menciptakan pembelajaran yang kondusif. Seorang guru harus mampu melakukan pemilihan dan penentuan strategi sesuai dengan tujuan pembelajaran yang telah dirumuskan. Melihat mulia dan agungnya profesi guru menjadi renungan untuk senantiasa meningkatkan profesionalitas yang dimiliki seorang guru melalui proses pembelajaran yang tidak kenal waktu (life long education). Guna memberikan layanan optimal terhadap siswa atau siswi maka dari itu lahirlah paradigma bahwa guru harus memiliki kompetensi pedagogik yang profesional atau dengan bahasa lain guru yang siap memberikan perubahan ke arah yang lebih berkualitas.

Paradigma demikian menyarankan guru untuk member siswa kesempatan untuk belajar lebih giat dan peerteaching kepada teman sebaya supaya mereka dapat saling mengisi satu sama yang lainnya. Untuk itu kompetensi menjadi ukuran kemampuan guru dalam mendidik agar menghasilkan profesionalisme yang diharapkan bangsa dan negara.

Profesionalisme adalah seseorang (guru) yang melakukan pekerjaan sesuai kewajiban sehingga bisa dipertanggungjawabkan dengan benar, mampu mengembangkan dan menyampaikan ilmu pengetahuan yang dimiliki agar dapat dinikmati oleh para penerima (siswa). Sedangkan guru professional adalah pendidik yang dapat menyatukan kualitas dan integritasnya.

Hal di atas sependapat dengan pernyataan Kunandar ${ }^{3}$, yang menyatakan bahwa profesionalisme guru merupakan kondisi, arah, nilai, tujuan, dan kualitas suatu keahlian dan kewenangan dalam bidang pendidikan dan pengajaran yang berkaitan dengan

${ }^{3}$ Deden Danil, "Upaya Profesionalisme Guru dalam Meningkatkan Prestasi Siswa di Sekolah (Study Deskriptif Lapangan di Sekolah Madrasah Aliyah Cilawu Garut)," Jurnal Pendidikan Universitas Garut 3, no. 1 (2009): 31, http://journal.uniga.ac.id/index.php/JP/article/view/21/20. diakses pada Hari Senin 15 April 2019

Profesionalisme Guru. Maulana 
pekerjaan seseorang yang menjadi mata pencaharian. Guru yang profesional diyakini mampu mengantarkan siswa dalam pembelajaran untuk menemukan, mengelola dan memadukan perolehannya, dan memecahkan persoalan-persoalan yang berkaitan dengan pengetahuan, sikap, dan nilai maupun keterampilan hidup mereka.

Selain itu, untuk menjadi guru professional harus memiliki karakteristik sebagaimana menurut Tilaar ${ }^{4}$ ialah sebagai berikut:

1. Memiliki kepribadian yang matang dan berkembang (mature and developing personality) sebagaimana dirumuskan Maister professionalism ispredominantly an attitude, not a set of competencies only. Guru professional adalah pribadipribadi unggul dan terpilih.

2. Menguasai ilmu pengetahuan dan teknologi yang kuat. Melalui dua hal ini guru professional akan menginspirasi anak didiknya dengan ilmu dan teknologi.

3. Menguasai keterampilan untuk membangkitkan minat dan potensi peserta didik.

4. Mengembangkan profesi yang berkesinambungan.

Dari sebutan karakteristik di atas dapat diambil makna bahwa untuk menjadi guru yang profesional tidak semudah apa yang dipikirkan. Artinya guru mampu menjadi seseorang yang profesional dengan berkembang, baik dalam wawasan, kreativitas, dan memilikiskill yang tinggi jika guru benar-benar memikirkan masa depan siswa, karena kepintaran bukan yang utama dimiliki guru, akan tetapi bagaimana siswa senang dan memahami setiap penyampaian materi dari guru.

Kemudian profesionalisme harus didorong dengan sebaik -baiknya sehinggaha setiap guru bisa mencapai tujuan yang dimaksudkan dalam UU Sisdiknas tahun 2003 tersebut. Artinya guru juga mampu memikat hati para siswa yaitu menjadi yang utama, baik jadi favorit ataupun idola agar menjadi yang terbaik di sisi mereka. Menurut Aziz ${ }^{5}$, paling tidak guru profesional yang menjadi favorit dan idola adalah guru yang KEREN:

${ }^{4}$ Y Suherman, Guru Spesialis Antara Generalis dan Spesialis (Bandung: CV Wahana Iptek, 2014), h. 67.

${ }^{5}$ Maulana Arafat Lubis, "Pengembangan Profesionalisme Guru Madrasah Ibtidaiyah Pada Abad 21 dalam Membuat Bahan Ajar Leaflet," INA-Rxiv, 2018, h. 8, https://doi.org/10.31227/osf.io/vsezk. 
a. Kuat karakternya dan Tangguh kepribadiannya.

b. Etos kerjanya tinggi dan penuh semangat.

c. Ramah dan senantiasa diliputi kasih sayang.

d. Egali tersikapnya, menganggap semua manusia sama dan sederajat.

e. Nastiti, cermat bertindak dan selalu berhati-hati dalam tutur kata.

Pendidikan Agama Islam (PAI) merupakan pengetahuan yang mengajarkan syariat Islam khususnya pada pendidikan formal. Pada lingkup sekolah umum pendidikan yang bersyariatkan Islam diajarkan pada mata pelajaran agama Islam, artinya seluruh ajaran Islam sudah include dalam mata pelajaran agama Islam, mata pelajaran agama Islam diajarkan di kelas biasanya dalam seminggu sekali. Sedangkan dalam lingkup Madrasah Ibtidaiyah (MI), PAI lebih banyak diajarkan di kelas dan lebih luas ilmu pengetahuan di dalamnya, seperti: mata pelajaran Bahasa Arab, Akidah Akhlak, Fikih, Sejarah Kebudayaan Islam, dan Quran Hadis. Sedangkan dalam lingkup Sekolah Dasar (SD), mata pelajarannya adalah pendidikan agama Islam dan budi pekerti yang di dalamnya mencakup Alquran dan Hadis, Keimanan, Akhlak, Fikih, dan Sejarah Peradaban Islam.

Oleh karena itu siswa yang menempuh pendidikan di sekolah umum sangat berbanding dengan siswa yang menempuh di madrasah dalam bidang agama Islam. Oleh karena itu untuk menanamkan keilmuan agama Islam terhadap siswa di SD membutuhkan ekstra yang kuat. Agar siswa SD tidak berbanding sebelah dengan siswa MI dalam kepemilikan ilmu pengetahuan agama Islam. Maka dari itu profesionalisme guru PAI dan budi pekerti di SD sangat diharapkan dalam memberikan pemahaman kepada siswa sehingga dapat setara dengan Madrasah Ibtidaiyah..

PAI bertujuan untuk menyempurnakan manusia dalam merealisasikan hidup dan penghidupannya untuk memperoleh ridha Allah SWT melalui kegiatan beriman, berilmu, beramal, yang dalam pendidikan umumnya disebut afektif, kognitif, dan psikomotorik. $^{6}$

Terlaksananya pembelajaran yang baik karena mengimplementasikan strategi dalam proses belajar mengajar. Oleh sebab itu, perlu pelaksanaan yang menjadi komitmen bagi setiap guru. Berikut strategi pembelajaran yang perlu dilaksanakan di

\footnotetext{
${ }^{6}$ Dja'far Siddik, Konsep Dasar PAI (Bandung: Cita Pustaka Media, 2006), h. 51. 
dalam metode-metode pembelajaran agar dapat terealisasi oleh siswa pada mata pelajaran PAI dan budi pekerti di SD: ${ }^{7}$

\section{MetodeHiwar}

Metodehiwar (dialog) ini terbagi kepada hiwar Qurani dan hiwar Nabawi, tetapi keduanya tetap merupakan dialog silih berganti antara dua pihak atau lebih, tentang suatu tema yang sengaja diarahkan kepada suatu tujuan yang dikehendaki. Metode ini biasa disebut diskusi.

\section{MetodeQisasi}

Metode qisasi (kisah) baik qisasi qurani maupun qisasi nabawi, kedua keduanya menekankan penuturan tentang kisah-kisah yang terdapat dalam Alquran maupun yang didasarkan pada sirahNabi. Penerapan metode qisasi ini sebagai metode pembelajaran pada bidang studi PAI mengandung nilai edukasi yang tinggi. Suatu kisah memang selalu mengikat dan mengandung pendengar untuk mengikuti peristiwa dan merenungkan maknanya. Selain itu kisah juga dapat menyentuh hati manusia karena menampilkan tokoh dalam konteksnya, sehingga pendengar dapat ikut menghayati dan merasakan isi kisah seolah-olah Dai sendiri yang menjadi pelakonnya. ${ }^{8}$

\section{MetodeAmsal}

Metode amsal (perumpamaan) ini biasanya digunakan oleh pendidik dengan pengungkapan yang hampir sama dengan metode qisasi yaitu dengan ceramah atau membaca teks. Kebaikan metode ini untuk mempermudah siswa dalam memahami konsep yang abstrak, merangsang kesan terhadap makna yang tersirat dalam perumpamaan tersebut, apalagi karenabahan pelajaran yang menggunakan metode ini menjadi lebih mudah dipahami, logis serta rasional. Metode ini juga memberikan motivasi untuk berbuat baik dan menjahui kejahatan, sebagai tujuan pokok pada penerapan metode ini.

${ }^{7}$ Abdurrahman An-Nahlawi, Usul Al-Tarbiyah Al Islamiyah Wa Asalibuha Fi Al-Baiti Wa AlMadrasah Wa Al-Mujtama (Bairut:Dar al-Fikr,1989), h. 283.

${ }^{8}$ Dja'far Siddik, Ilmu Pendidikan Islam (Bandung: Cipta Pustaka Media, 2006), h. 138. 


\section{Metodeal-Adah}

Inti sari dari al-Adah (pembiasaan) ini adalah pengulangan. Jika pendidik setiap masuk kelas mengucapkan salam, maka hal itu dapat diartikan sebagai usaha pembiasaan. Bila siswa telah dibiasakan berpakaian bersih dan rapi setiap datang ke sekolah/ madrasah, berarti sudah menerapkan metode ini. Bila siswa memasuki kelas tidak mengucapkan salam, maka pendidik mengingatkannya agar masuk ruangan hendaknya mengucapkan salam, termasuk dari penerapan metode ini.

\section{Metode al-Qudwah}

Metode al-Qudwah (keteladanan) ini memang berpusat pada siswa. Keteladanan personal para pendidik merupakan keberhasilan dalam menerapkan metode ini. Metode pembiasaan, (al-adah) dikatakan efektif untuk pembentukan sikap dan nilai-nilai, karena siswa mengikuti guru, jika gurunya tidak berwibawa, maka siswa menjadi tidak segan. Oleh sebab itu, keteladanan bisa menjadi ujung tombak pengetahuan seseorang. Itulah sebabnya keteladanan pendidik merupakan prasyarat bagi keberhasilan pendidikan.

\section{Metodeal-Ibrahwa al-Mau'ziah}

Pendidikan Islam memberikan perhatian khusus kepada metode al-Ibrah (iktibar) agar siswa dapat mengambil kisah-kisah dalam Alquran dan Hadis serta tokoh-tokoh Al-salaf Al-saleh bukanlah semata-mata dari aspek historisnya saja, melainkan pelajaran penting yang terdapat di dalamnya sebagai sesuatu yang berharga untuk diambil dan diimplementasikan dalam kehidupan sehari-hari.

Sedangkan metode mauzi'ah (pengajaran melalui nasehat) merupakan metode yang cukup efektif untuk menyentuh hati dan perasaan, karena metode mauzi'ah pada dasarnya adalah nasihat yang lemah lembut dan senga jadi buat untuk menyentuh akal budi dan perasaan siswa secara langsung.

\section{Metodeal-Targibwa al-Tarhib}

Metode al-Targib wa al-Tarhib ini didasarkan atas fitrah manusia yang menginginkan kebahagiaan, kesenangan, dan keselamatan serta tidak menginginkan 
kepedihan dan kesengsaraan. Metode ini merupakan metode andalan dalam Pendidikan Islam yang tidak menginginkan adanya hukuman dan ganjaran, kecuali dalam konteks sebagai satu-satunya jalan yang bisa ditempuh.

\section{METODE PENELITIAN}

Penelitian ini merupakan penelitian lapangan (field research) yang bersifat deskriptif kualitatif. Penelitian kualitatif adalah penelitian yang dilakukan secara wajar, natural, dan original sesuai kondisi objektif di lapangan tanpa adanya rekayasa. Penelitian ini menggunakan metode kualitatif yang mana peneliti menelaah maupun mencari data-data sesuai keadaan yang sebenarnya di lapangan secara murni dan apa adanya.

Penelitian ini bertujuan untuk menggambarkan Profesionalisme Guru Mata Pelajaran PAI dan Budi Pekerti di SD 200205 Padangsidimpuan.

Penelitian ini bertempat di SD 200205 Padangsidimpuan jalan Imam Bonjol gang Pendidikan kelurahan Aek Tampang Kecamatan Padangsidimpuan Selatan Kota Padangsidimpuan Provinsi Sumatera Utara. Waktu yang dibutuhkan pada penelitian ini adalah 3 bulan, yaitu dari bulan Januari s.d Maret 2019. Penelitian ini memfokuskan keprofesionalan guru mata pelajaran agama Islam di SD 200205 Padangsidimpuan.

Teknik pengumpulan data dalam penelitian ini adalah wawancara dan dokumentasi. Metode wawancara dalam penelitian ini digunakan sebagai metode pengumpulan data utama. Wawancara menurut Nurdiani ${ }^{9}$ merupakan salah satu metode pengumpulan data dengan cara komunikasi antara pengumpul data dengan sumber data. Melalui wawancara, responden diberi kesempatan untuk menyampaikan pendapatnya sendiri.

Kemudian, sumber data pada penelitian ini ialah siswa, stakeholder, dan kepala sekolah SD 200205 Padangsidimpuan. Poin-poin pertanyaan yang akan disampaikan kepada sumber data adalah tentang kemampuan guru mata pelajaran agama Islam pada proses pembelajaran di kelas, baik dalam penguasaan materi pelajaran agama Islam, penggunaan media pembelajaran, strategi pembelajaran, dan perangkat pembelajaran.

\footnotetext{
9Moh Masnun, Syibli Maufur, dan Ahmad Arifuddin, "Respon Stakeholders Terhadap Kurikulum Berbasis Keran\&ka Kualifikasi Nasional Indonesia (KKNI) Jurusan PGMI IAIN Syekh Nurjati Cirebon," $A L$ IBTIDA: Jurnal Pendidikan Guru MI5, no.1(2018), h. 30, https://doi.or8/10.24235/al.ibtida.snj.v5i1.2479.
} 
Selanjutnya, metode dokumentasi adalah suatu metode untuk mencari data riil berupa catatan-catatan yang dianggap penting. Dokumentasi yang digunakan berupa lembar pertanyaan wawancara dan foto ketika wawancara dengan sumber data.

Setelah data diperoleh, data tersebut diuji kesahihannya menggunakan teknik pemeriksaan triangulasi data. Triangulasi data merupakan teknik pengecekan data dari berbagai sumber, cara, dan waktu. ${ }^{10}$ Pelaksanaan yang dilakukan dalam penelitian ini menggunakan teknik triangulasi sumber, yang mana peneliti membandingkan data yang diperoleh melalui instrumen yang berbeda pada data hasil pengamatan dan hasil wawancara, dan membandingkan hasil wawancara dengan isi dokumen.

Adapun analisis data dalam penelitian ini dilakukan di lapangan dengan menggunakan metode deskriptif analitik, artinya penelitian ini nantinya akan disusun dengan cara mendeskripsikan maupun menafsirkan data yang telah ditemukan di lapangan.

\section{HASIL DAN PEMBAHASAN}

Berdasarkan temuan yang dapat diperoleh oleh peneliti di lapangan dapat dipahami bahwa, ada beberapa temuan yang perlu dipaparkan dalam hasil temuan ini. Temuan ini adalah sebagai berikut.

\section{A. Tanggapan Siswa Terhadap Profesionalisme Guru PAI dan Budi Pekerti}

Berdasarkan hasil wawancara dengan siswa SD 200205 Padangsidimpuan, wawancara diajukan kepada perwakilan dari setiap kelas baik dari kelas 1 s.d 6. Hasil wawancara diperoleh informasi bahwa tanggapan siswa terhadap profesionalisme guru pada aspek penguasaan materi pelajaran PAI dan budi pekerti sudah sesuai harapan. Menurutnya, guru sangat jelas dalam menyampaikan materi pelajaran PAI dan budi pekerti di kelas, karena sifatnya yang tegas dan kejam dapat membuat siswa takut dan harus memperhatikan guru ketika mengajar. Selain itu penjelasan materi yang disampaikan dapat dimengerti dengan mudah, karena materi dikaitkan dalam kehidupan sehari-hari.

Sementara itu, pada aspek penggunaan media pembelajaran, siswa memberi tanggapan bahwa guru mata pelajaran PAI dan budi pekerti ketika menyampaikan

${ }^{10}$ Sugiuono, Metode Penelitian Pendidikan: Pendekatan Kuantitatif, Kualitatit, dan RED (Bandung: Alfabeta, 2013), h. 19.

Profesionalisme Guru. Maulana 
ataupun menjelaskan materi selalu menggunakan media yang dapat mendorong pemahaman siswa. Media yang sering dibawa dan digunakan di kelas ialah media visual berupa gambar. Tetapi tergantung materi yang akan disampaikan guru, jika meterinya terkait Fikih, maka guru menggunakan media video. Jika materinya terkait Alquran dan Hadis, maka guru menggunakan media buku cetak ataupun Alquran. Jika materinya terkait akidah akhlak sering diperhatikan guru tidak pernah menggunakan media dan hanya menjelaskan materi saja.

Selanjutnya, pada aspek strategi pembelajaran, siswa beranggapan bahwa guru mata pelajaran agama Islam masih jauh dari harapan yang mana menjelaskan materi dengan menggunakan metode ceramah dan praktik, sehingga terkadang pembelajaran sangat membosankan karena tidak ada yang menyenangkan ketika belajar sehingga suasana menjadi monoton.

Kemudian pada aspek perangkat pembelajaran, siswa menanggapi belum sesuai dengan harapan bahwa guru tidak pernah membawa Rencana Pelaksanaan Pembelajaran (RPP) ke dalam kelas, yang di bawahanya absensi dan buku paket saja. Terkadang guru hanya menjelaskan materi saja dan jarang memberi penilaian di dalam kelas.

Dari uraian hasil wawancara di atas dapat disimpulkan bahwa tanggapan siswa terhadap profesionalisme guru mata pelajaran PAI dan budi pekerti sudah dikategorikan baik. Namun, ada sedikit yang perlu dibenahi, yakni perlakuan apersepsi dalam kegiatan pembuka dan refleksi pada kegiatan penutup dalam mengajar, agar kemantapan materi yang disampaikan tercapai. Kemudian perlu penguatan teori dalam strategi mengajar dan dikolaborasikan dengan media sehingga pembelajaran yang menyenangkan dapat terimplementasi dengan sempurna.

\section{B. Tanggapan Stakeholder Terhadap Profesionalisme Guru PAI dan Budi Pekerti}

Berdasarkan hasil wawancara dengan Stakeholder di daerah Padangsidimpuan yaitu Dr. Muhammad Roihan Daulay, M.A yang adalah praktisi pendidikan, kepala madrasah, dan dosen Tarbiyah dan Ilmu Keguruan IAIN Padangsidimpuan dalam bidang pendidikan agama Islam. Hasil wawancara diperoleh informasi bahwa tanggapan Stakeholder terhadap profesionalisme guru pada aspek penguasaan materi pelajaran PAI 
dan budi pekerti sudah sesuai harapan. Menurutnya, guru tersebut adalah sarjana pendidikan agama Islam sehingga dalam pengusaan materi sudah tidak diragukan lagi.

Sementara itu, pada aspek penggunaan media pembelajaran, hasil wawancara kepada Stakeholder diperoleh bahwa guru mata pelajaran PAI dan budi pekerti ketika menyampaikan ataupun menjelaskan materi biasanya tetap menggunakan media pembelajaran, akan tetapi media yang digunakan masih belum efektif dan efisien sehingga media pembelajaran tidak terintegrasi dengan baik. Maka harapannya agar guru mata pelajaran PAI dan budi pekerti dapat diajarkan dengan baik dan benar melalui sinkronisasi antara materi dan media. Termasuk bagaian yang sangat fundamental adalah kekurang mampuan guru dalam memainkan Informasi dan teknologi dapat mengakibatkan lemahnya guru dalam menentukan media apa yang sepantasnya diberikan sehingga peserta didik akan lebih mudah memahami terkait dengan materi yang diajarkan.

Selanjutnya, pada aspek strategi pembelajaran, Stakeholder menyatakan bahwa guru matapelajaran PAI dan budi pekerti sangat sesuai dengan materi yang akan diajarkan. Seringkali melakukan praktik menjadikan siswa dapat aktif dalam belajar, misalnya saja tata cara shalat maupun bersuci pada materi fikih, dan pada materi Alquran dapat melafalkan ayat-ayat pendek. Itulah kelebihan yang dimiliki mata pelajaran PAI dan budi pekerti, bukan hanya dihafal, tetapi menjadi pelaksanaan yang dilakukan setiap hari baik di rumah, di sekolah, maupun lingkungan sekitar masih jauh dengan apa yang diharapkan. Oleh karena itu, menurut peneliti sudah sewajarnya guru tampil sebagai sosok yang dapat mempraktekkan tata cara salat dalam konteks realitas dan bukan hanya sekedar konseptualitas belaka.

Kemudian pada aspek perangkat pembelajaran Stakeholder menyampaikan bahwa guru mata pelajaran PAI dan budi pekerti masih lalai dalam mementingkan perangkat pembelajaran. Terkadang guru sering melupakan sesuatu yang sebenarnya sangat berpengaruh suksesnya suatu pelaksanaan pembelajaran seperti program tahunan, program semester, silabus, RPP, dan penilaian. Padahal agar tersusunnya alur kegiatan pembelajaran yaitu melalui perangkat pembelajaran. Jadi untuk kesediaan perangkat pembelajaran sebelum memulai mengajar masih kurang harapan.

Dari uraian hasil wawancara di atas dapat disimpulkan bahwa tanggapan Stakeholder terhadap profesionalisme guru mata pelajaran PAI dan budi pekerti sudah 
baik. Namun, perlu dikembangkan sehingga menjadi inovasi pembaharuan zaman, karena perubahan zaman menjadi tantangan berat dalam menanamkan nilai-nilai keislaman pada jiwa dan raga siswa. Seyogianya ajaran agama Islam perlu ditanamkan sedasar mungkin, agar mereka menjadi siswa yang memiliki keimanan maupun ketakwaan sesuai ajaran agama Islam yang berlandaskan Alquran dan sunnah/ hadis sehingga terhindar dari ajaran-ajaran yang radikal seperti adanya kebebasan siswa tanpa batas, guru mengajar dengan sesukanya menjadi koreksian besar-besaran oleh kita semua. Sesuai dengan pemaparan di atas dapat dipahami bahwa setiap guru harus benarbenar tampil sebagai pigur, dan tidak hanya sebatas formalitas.

\section{Tanggapan Kepala Sekolah Terhadap Profesionalisme Guru PAI dan Budi Pekerti}

Berdasarkan hasil wawancara dengan Kepala Sekolah SD 200205 Padangsidimpuan bahwa profesionalisme guru pada aspek penguasaan materi pelajaran PAI dan budi pekerti sudah sesuai harapan. Menurutnya, guru mata pelajaran PAI dan budi pekerti sudah baik dalam mengajar, hanya saja tujuan pembelajaran jarang disampaikan kepada siswa.

Sementara itu, pada aspek penggunaan media pembelajaran, hasil wawancara kepada Kepala Sekolah SD 200205 Padangsidimpuan diperoleh bahwa guru mata pelajaran PAI dan budi pekerti selalu menggunakan media sebagai alat bantu dalam menjelaskan materi pelajaran. Fasilitas dari sekolah berupa media pembelajaran khusus mata pelajaran PAI dan budi pekerti masih belum memadai, tetapi guru tersebut selalui menyiapkan media yang akan diajarkan, misalnya gambar yang dihasilkan dari internet dan di print, bahkan boneka juga dibawa sebagai media jika materinya tentang fikih. Selain itu guru juga memanfaatkan kamar mandi untuk mempraktikkan tata cara bersuci.

Selanjutnya, pada aspek strategi pembelajaran, Kepala Sekolah SD 200205 Padangsidimpuan menyatakan bahwa guru matapelajaran PAI dan budi pekerti sangat sesuai dengan materi yang akan diajarkan. Seringkali melakukan praktik, misalnya saja tata cara shalat, sedekah, maupun infak, dan tata cara berwudhu maupun tayamum pada materi fikih, dan pada materi Alquran dapat melafal dan menghafal surah pilihan. 
Kemudian pada aspek perangkat pembelajaran Kepala Sekolah SD 200205 Padangsidimpuan menyampaikan bahwa guru mata pelajaran PAI dan budi pekerti belum konsisten dalam administrasi, salah satunya perangkat pembelajaran. Kebiasan yang sering dilakukan ialah guru membuat perangkat pembelajaran selalu dipertengahan semester, bukan di awal semester. Inilah yang menyebabkan guru kurang memperhatikan sistematika pengajaran sehingga materi pelajaran sering kurang efisien. Itulah betapa pentingnya perangkat pembelajaran sebelum mengajar.

Dari uraian hasil wawancara di atas dapat disimpulkan bahwa tanggapan Kepala Sekolah SD 200205 Padangsidimpuan terhadap profesionalisme guru mata pelajaran PAI dan budi pekerti perlu di perketat aturan dalam penyiapan laporan administrasi termasuk perangkat pembelajaran. Karena guru yang tidak mampu membuat perangkat pembelajaran bukan termasuk guru yang professional. Karena keprofesionalan guru dilihat bukan dari satu aspek saja, melainkan dari beberapa aspek, termasuk aspek penguasaan materi, penggunaan media pembelajaran, penerapan strategi pembelajaran, dan perangkat pembelajaran. Untuk itu guru dituntut hanya pandai dalam menguasai materi saja, tetapi mampu menyampaikan materi dengan berbagai cara melalui strategi pembelajaran beserta media sehingga siswa dengan mudah menyerap ilmu pengetahuan yang disampaikan guru. Selain itu mampu menyusun rencana pembelajaran ke dalam perangkat pembelajaran.

Dari hasil penelitian yang telah diuraikan di atas menunjukkan bahwa secara umum tanggapan siswa, stakeholder, dan Kepala Sekolah SD 200205 Padangsidimpuan terhadap guru mata pelajaran Pendidikan Agama Islam dan Budi Pekerti sudah baik. Namun, perlu pembaharuan dalam inovasi pembelajaran PAI agar matapelajaran ini dapat dicintai dan tertanam pada benaksiswa SD.

Selain itu, penguasaan materi pelajaran PAI dan budi pekerti, media pembelajaran, strategi pembelajaran, dan perangkat pembelajaran adalah ujung tombak kesuksesan guru dalam mentransfer ilmu pengetahuan kepada siswa. Dari aspek-aspek tersebut dapat meningkatkan profesionalisme guru dalam mengajar, karena tanpa pengamalan aspek tersebut guru dapat dikatakan gadungan. Artinya guru yang hanya mengharapkan gaji semata, bukan memikirkan masa depan siswa ke depannya.

\section{PENUTUP}


Penutup dari penelitian ini berisikan kesimpulan yang diperoleh dari sumber data, yakni dari siswa, stakeholder, dan kepala sekolah SD 200205 Padangsidimpuan. Isi data data tersebut ditemukannya pernyataan dari siswa bahwa profesionalisme guru mata pelajaran PAI dan budi pekerti sudah baik. Namun, ada sedikit yang perlu dibenahi, yakni perlakuan apersepsi dalam kegiatan pembuka dan refleksi pada kegiatan penutup dalam mengajar, agar kemantapan materi yang disampaikan tercapai. Kemudian perlu penguatan teori dalam strategi mengajar dan dikolaborasikan dengan media sehingga pembelajaran yang menyenangkan dapat terimplementasi dengan sempurna.

Sedangkan pernyataan dari stakeholder terhadap profesionalisme guru mata pelajaran PAI dan budi pekerti sudah baik. Namun, perlu dikembangkan sehingga menjadi inovasi pembaharuan zaman, karena perubahan zaman menjadi tantangan berat dalam menanamkan nilai-nilai keislaman pada jiwa dan raga siswa. Seyogianya ajaran agama Islam perlu ditanamkan sedasar mungkin, agar mereka menjadi siswa yang memiliki keimanan maupun ketakwaan sesuai ajaran agama Islam yang berlandaskan Alquran dan sunnah/ hadis sehingga terhindar dari ajaran-ajaran yang radikal.

Selanjutnya pernyataan dari kepala sekolah SD 200205 Padangsidimpuan terhadap profesionalisme guru mata pelajaran PAI dan budi pekerti perlu diperketat aturan dalam penyiapan laporana dministrasi termasuk perangkat pembelajaran. Karena guru yang tidak mampu membuat perangkat pembelajaran bukan termasuk guru yang professional. Karena keprofesionalan guru dilihat bukan dari satu aspek saja, melainkan dari beberapa aspek, termasuk aspek penguasaan materi, penggunaan media pembelajaran, penerapan strategi pembelajaran, dan perangkat pembelajaran.

Dengan demikian guru dituntut hanya pandai dalam menguasai materi saja, tetapi mampu menyampaikan materi dengan berbagai cara melalui strategi pembelajaran beserta media sehingga siswa dengan mudah menyerap ilmu pengetahuan yang disampaikan guru. Selain itu mampu menyusun rencana pembelajaran ke dalam perangkat pembelajaran secara komunikatif dan terkoneksi secara baik dan benar.

\section{DAFTAR PUSTAKA}

An-Nahlawi, Abdurrahman. Usul Al-Tarbiyah Al- Islamiyah Wa Asalibuha Fi Al-Baiti Wa Al-Madrasah Wa Al-Mujtama. Bairut: Dar al-Fikr, 1989. 
Danil, Deden. "Upaya Profesionalisme Guru dalam Meningkatkan Prestasi Siswa di Sekolah (Study Deskriptif Lapangan di Sekolah Madrasah Aliyah Cilawu Garut)." Jurnal Pendidikan Universitas Garut 3, no. 1 (2009): 20-40. http://journal.uniga.ac.id/index.php/JP/article/view/21/20.

Hasbullah. Dasar-Dasar Ilmu Pendidikan. Jakarta: PT Raja Grafindo Persada, 2008.

Lubis, Maulana Arafat. "Pengembangan Profesionalisme Guru Madrasah Ibtidaiyah Pada Abad 21 dalam Membuat Bahan Ajar Leaflet." INA-Rxiv, 2018. https://doi.org/10.31227/osf.io/vsezk.

Masnun, Moh, Syibli Maufur, dan Ahmad Arifuddin. "Respon Stakeholders Terhadap Kurikulum Berbasis Kerangka Kualifikasi Nasional Indonesia (KKNI) Jurusan PGMI IAIN Syekh Nurjati Cirebon.” AL IBTIDA: Jurnal Pendidikan Guru MI 5, no. 1 (2018): 25-38. https://doi.org/10.24235/al.ibtida.snj.v5i1.2479.

Siddik, Dja'far. Ilmu Pendidikan Islam. Bandung: Cipta Pustaka Media, 2006. Konsep Dasar PAI. Bandung: Cita Pustaka Media, 2006.

Sugiyono. Metode Penelitian Pendidikan: Pendekatan Kuantitatif, Kualitatif, Dan $R \& D$. Bandung: Alfabeta, 2013.

Suherman, Y. Guru Spesialis Antara Generalis dan Spesialis. Bandung: CV Wahana Iptek, 2014. 